\title{
Influence of sildenafil and buflomedil on survival of randomized flaps in rats: an experimental study
}

\author{
Influência do buflomedil e do sildenafil na sobrevivência de retalhos \\ randomizados em ratos: estudo experimental
}

\author{
Jason C. Abrantes \\ Figueiredo $^{1}$ \\ Antonio Gustavo Zampar ${ }^{2}$ \\ Cristina Destro ${ }^{3}$ \\ Victor Eduardo A. Arias ${ }^{4}$ \\ Rebeca Morro 5 \\ AdivÂNIA DE SOUZA \\ PINHEIRO $^{6}$ \\ José Marcos de Andrade \\ MÉLEGA
}

Study conducted at Instituto de Cirurgia Plástica Santa Cruz, São Paulo, SP, Brazil.

Submitted to SGP (Sistema de Gestão de Publicações/Manager Publications System) of RBCP (Revista Brasileira de Cirurgia

Plástica/Brazilian Journal of Plastic Surgery).

Received: April 5, 2011

Accepted: August 18, 2011

\begin{abstract}
Background: Microcirculation dysfunction, as a consequence of localized vascular insufficiency, is considered to be one of the dominant causes of surgical flap necrosis. Several vasoactive drugs have been tested for the pharmacological treatment of tissue ischemia, with varying degrees of success. This study aimed to assess the impact of buflomedil and sildenafil on the viability of random skin flaps in rats. Methods: Caudally pedicled skin flaps $(10 \times 3 \mathrm{~cm})$ were created on the backs of rats. The animals were randomly assigned, in groups of 10 , to three treatment groups: one group served as the vehicle control group, one group received buflomedil $(10 \mathrm{mg} / \mathrm{kg} / \mathrm{d}$, orally), and a third group received the same dosage of sildenafil. Following seven days of dosing, the animals were sacrificed, and the viable flap area was determined. Results: The average viable flap area for each group was: $16.2 \pm 3.56 \mathrm{~cm}^{2}$ (control group), $17.69 \pm 2.54 \mathrm{~cm}^{2}$ (buflomedil group), and $18.28 \pm 3.74 \mathrm{~cm}^{2}$ (sildenafil group). Data analysis by the Kruskal-Wallis test failed to show a statistically significant difference between the three groups. Conclusions: Neither buflomedil nor sildenafil showed a reduction in the necrotic area of random skin flaps in rats.
\end{abstract}

Keywords: Surgical flaps. Piperazines. Pyrrolidines. Necrosis/prevention \& control. Rats.

\section{RESUMO}

Introdução: A insuficiência no aporte sanguíneo e a consequente disfunção gerada no fluxo da microcirculação são consideradas causas dominantes de sofrimento de um retalho cirúrgico. Várias drogas vasoativas têm sido testadas para o tratamento farmacológico da isquemia tecidual, porém com graus variáveis de sucesso. Este estudo teve como objetivo avaliar a influência do buflomedil e do sildenafil na viabilidade de retalhos cutâneos ao acaso, em ratos. Método: Foram confeccionados retalhos cutâneos no dorso de ratos, com dimensões de 10 x $3 \mathrm{~cm}$ e base caudal. Foram utilizados 30 ratos, divididos em três grupos de 10 ratos cada: um grupo que recebeu apenas o veículo da solução (grupo controle); um grupo que recebeu buflomedil (grupo buflomedil); e um terceiro grupo que recebeu sildenafil (grupo sildenafil). A via de administração foi a oral e a dose foi de $10 \mathrm{mg} / \mathrm{kg} /$ dia para cada droga, durante sete dias. Ao final desse período, os animais foram sacrificados, sendo realizada a determinação das áreas viáveis dos retalhos. Resultados: A média das áreas viáveis dos retalhos foi de 16,2 $\pm 3,56 \mathrm{~cm}^{2}$ para o grupo controle, de $17,69 \pm 2,54 \mathrm{~cm}^{2}$ para o grupo buflomedil, e de 18,28 $\pm 3,74 \mathrm{~cm}^{2}$ para o grupo sildenafil. A análise dos dados pelo teste de Kruskal-Wallis não demonstrou significância estatística entre os três grupos. Conclusões: A utilização do buflomedil e do sildenafil demonstrou não diminuir a área de necrose de retalhos randomizados em ratos.

Descritores: Retalhos cirúrgicos. Piperazinas. Pirrolidinas. Necrose/prevenção \& controle. Ratos.

1. Ph.D. at Universidade de São Paulo (USP), full member of the Brazilian Society of Plastic Surgery (SBCP), assistant physician at Instituto de Cirurgia Plástica Santa Cruz, São Paulo, SP, Brazil.

2. Associate member of SBCP, fellow assistant physician at Instituto de Cirurgia Plástica Santa Cruz, São Paulo, SP, Brazil.

3. Associate member of SBCP, plastic surgeon, former resident at Instituto de Cirurgia Plástica Santa Cruz, São Paulo, SP, Brazil.

4. Ph.D. at USP, pathologist at Hospital Santa Cruz, São Paulo, SP, Brazil.

5. Pharmacist at Hospital Santa Cruz, São Paulo, SP, Brazil.

6. Postgraduate studies at USP-Ribeirão Preto, resident physician at Instituto de Cirurgia Plástica Santa Cruz, São Paulo, SP, Brazil.

7. Full member of SBCP, head of the Plastic Surgery Service of Instituto de Cirurgia Plástica Santa Cruz, São Paulo, SP, Brazil. 


\section{INTRODUCTION}

Despite improvements in plastic surgery, necrosis remains a major complication in the cosmetic use of skin flaps. Its occurrence can have a devastating impact on the envisioned result. Insufficient blood supply to the skin flap and the consequent microcirculation dysfunction are considered to be the dominant causes of necrosis in surgical flaps ${ }^{1,2}$. Different vasoactive drugs have been tested, with varying degrees of success, on improving localized ischemia, and a standard reference drug for the pharmacological treatment of tissue ischemia has not been identified to date ${ }^{3-5}$.

Buflomedil has been clinically used to treat peripheral circulatory deficits. Previously published studies have indicated that this drug decreases peripheral vascular resistance resulting in increased blood perfusion ${ }^{6-8}$.

Phosphodiesterase (PDE) inhibitors have also been studied for their vasodilating effects. PDEs are a group of related enzymes, comprised of 11 subtypes, that cleave c-AMP (cyclic adenosine monophosphate) and/or c-GMP (cyclic guanosine monophosphate), inactivating it. Sildenafil is a type 5 PDE inhibitor, which acts specifically on c-GMP molecules abundant in smooth muscle cells such as those found in vessel walls ${ }^{5,9}$. When endothelial cells release nitric oxide, it diffuses into the smooth muscle cells of the microvasculature and binds guanylate cyclase, activating it and leading to the formation of $\mathrm{c}-\mathrm{GMP}^{10}$. c-GMP, in turn, acts to relax myosin (a protein in the vessel walls), resulting in vessel dilation. Thus, sildenafil's inhibition of the enzyme that cleaves c-GMP would be expected to result in an increased concentration of c-GMP, with consequent vasodilation ${ }^{5,9}$.

This study aimed to assess the impact of buflomedil and sildenafil on tissue viability in randomized skin flaps.

\section{METHODS}

Thirty adult, male, Wistar rats weighing 250-280 g were used in this study. The animals were kept in the climate controlled animal laboratory of Instituto de Cirurgia Plástica Santa Cruz (São Paulo, SP, Brazil), with water and feed ad libitum, for one week prior to the study. Animals were treated in accordance to the resolutions of the Brazilian Association of Animal Experimentation (COBEA).

Anesthesia was induced by intraperitoneal administration of a mixture of ketamine $(100 \mathrm{mg} / \mathrm{ml})$ and xylazine $(20 \mathrm{mg} /$ $\mathrm{ml}$ ) at a total dose of $0.2 \mathrm{ml}$ per $100 \mathrm{mg}$ of body weight. The backs of the animals were shaved and cleaned with an antiseptic. Thereafter, a skin flap with a caudal pedicle $(10 \times 3 \mathrm{~cm})$ was made on the back of each animal with sterile instruments; the iliac crests served as anatomical reference points for the beginning of each flap (Figure 1). The flap was elevated above the panniculus carnosus and then continuously resutured to the wound bed using 4-0 monofilament nylon. The flaps were sutured in place on the wound bed with markings placed every $2 \mathrm{~cm}$ along the flap length in order to facilitate observation of the necrotic area (Figures 1 and 2).

The animals were randomly divided into three groups, with 10 animals in each group: control group, to which only the vehicle solution was administered; sildenafil group, to which a solution containing sildenafil was administered; and buflomedil group, to which a solution containing buflomedil was administered.

The suspensions were previously prepared in a laboratory and the drug vehicle consisted of a 1:1 mixture of $1 \%$ carboxymethylcellulose and a simple syrup, prepared according to the Brazilian Pharmacopoeia IV- $4^{\text {th }}$ ed. (1988). Seven bottles containing $300 \mathrm{~mL}$ of the vehicle were prepared. Four bottles were used in the preparation of the suspensions, as described below, and three were reserved for the control group.

The sildenafil suspension was prepared by grinding 30 Viagra ${ }^{\circledR}$ tablets $(50 \mathrm{mg})$ into a fine powder, which was suspended in the above-mentioned vehicle to form a paste. The paste was subsequently mixed with $1 \%$ carboxymethylcellulose and simple syrup in a test tube to obtain a final

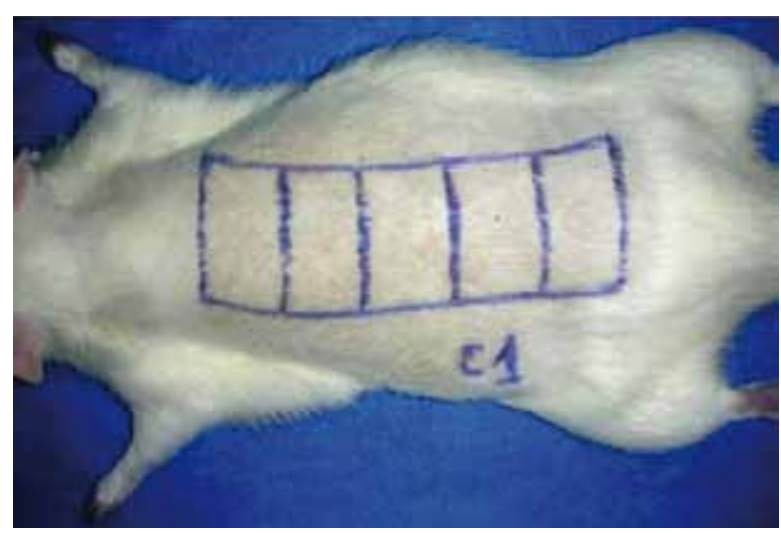

Figure 1 - Flap $(10 \times 3 \mathrm{~cm})$ created on the back of a rat with transverse marks every $2 \mathrm{~cm}$ to observe the necrotic area.

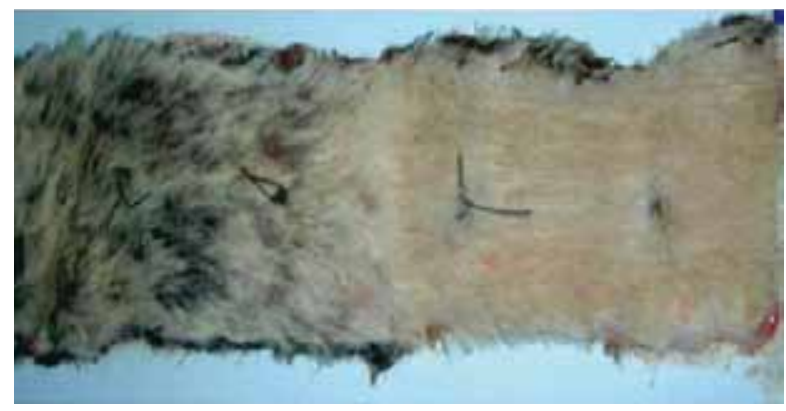

Figure 2-Delimitation between the area of necrosis and the viable area of the flap (repair sutures every $2 \mathrm{~cm}$ ). 
volume of $600 \mathrm{~mL}(2.5 \mathrm{mg} / \mathrm{mL}$, final concentration) and stored in two opaque plastic bottles $(300 \mathrm{~mL} /$ bottle $)$.

The buflomedil suspension was prepared by mixing a fine powder of 5 tablets of Bufedil ${ }^{\circledR} 300 \mathrm{mg}$ with the base vehicle of a 1:1 mixture of $1 \%$ carboxymethylcellulose and a simple syrup to form a paste. This paste was transferred to a test tube, and the volume was made up to $600 \mathrm{~mL}$ to obtain a concentration of $2.5 \mathrm{mg} / \mathrm{mL}$. The suspension was then transferred to two opaque plastic bottles of $300 \mathrm{~mL}$ each.

The solutions were administered by oral gavage. The first dose was administered in the immediate postoperative period and the remaining doses were administered once a day, for 7 days. The daily dose of sildenafil and buflomedil was $10 \mathrm{mg} / \mathrm{kg}$, with an equivalent volume of vehicle administered to the control group animals.

Post-surgery, the animals were kept in individual cages and the flaps were observed and photographed for seven days. At the end of this period, the rats were sacrificed. The viable area of the flap was designed and transposed to a paper carton (Figure 2), which was scanned and analyzed using Image Tool $2.0^{\circledR}$, a specific software designed for area calculation.

The flaps were cleaved and fixed in $10 \%$ formalin and a tissue slice, representing the viable area, was processed in a gradient of alcohol and xylene solutions. The dehydrated tissue was embedded in paraffin, sectioned ( $4 \mu \mathrm{m}$ thick) and stained with hematoxylin and eosin. The images were scanned and the vessel diameters were calculated using Image Tool $2.0^{\circledR}$.

The results were statistically analyzed using the KruskalWallis test.

\section{RESULTS}

The average viable areas of the flaps from each group were $16.2 \pm 3.56 \mathrm{~cm}^{2}$ (control group), $17.69 \pm 2.54 \mathrm{~cm}^{2}$ (buflomedil group), and $18.28 \pm 3.74 \mathrm{~cm}^{2}$ (sildenafil group) (Tables 1 and 2 , Figure 3). Data analysis showed no statistically significant difference among the three groups $(\mathrm{H}=1.6475$; degrees of freedom $=2 ; \mathrm{P}=0.4388$ ).

The average vessel diameter observed in flaps from the buflomedil group was $38.35 \mu \mathrm{m}$ (median $=34.25 \mu \mathrm{m}$; standard deviation $=19.85)$; from the control group, 27.1 $\mu \mathrm{m}($ median $=24.75 \mu \mathrm{m}$; standard deviation $=12.8)$; and from the sildenafil group, $19.9 \mu \mathrm{m}$ (median $=18.5 \mu \mathrm{m}$; standard deviation $=6.99)$. Statistical analysis indicated a statistical difference in at least one of the groups $(\mathrm{P}=$ 0.02 ); the post-test, using the method of Dunn's multiple comparisons, revealed significant differences between the buflomedil and sildenafil groups, without a significant difference between either treatment group and the control groups (Figure 4).
Table 1 - Viable flap areas from individual animals $\left(\mathrm{cm}^{2}\right)$

\begin{tabular}{c|c|c|c}
\hline Rats $(\mathbf{n}=\mathbf{1 0})$ & $\begin{array}{c}\text { Control } \\
\text { group }\end{array}$ & $\begin{array}{c}\text { Sildenafil } \\
\text { group }\end{array}$ & $\begin{array}{c}\text { Buflomedil } \\
\text { group }\end{array}$ \\
\hline 1 & 12.34 & 14.84 & 18.85 \\
\hline 2 & 20.87 & 22.54 & 18.79 \\
\hline 3 & 14.4 & 18.53 & 17.9 \\
\hline 4 & 12.04 & 13.55 & 18.48 \\
\hline 5 & 11.39 & 15.75 & 13.13 \\
\hline 6 & 15.75 & 14.69 & 20.23 \\
\hline 7 & 20.58 & 21.66 & 17.47 \\
\hline 8 & 19.37 & 24.18 & 21.61 \\
\hline 9 & 17.72 & 16.53 & 14.95 \\
\hline 10 & 17.54 & 20.53 & 15.53 \\
\hline $\mathrm{n}=$ total number of rats in each group.
\end{tabular}

Table 2 - Average viable areas of flaps after seven days $\left(\mathrm{cm}^{2}\right)$.

\begin{tabular}{l|c}
\hline Group & $\begin{array}{c}\text { Average } \pm \text { standard } \\
\text { deviation }\end{array}$ \\
\hline Control & $16.2 \pm 3.56$ \\
\hline Buflomedil & $17.69 \pm 2.54$ \\
\hline Sildenafil & $18.28 \pm 3.74$ \\
\hline
\end{tabular}

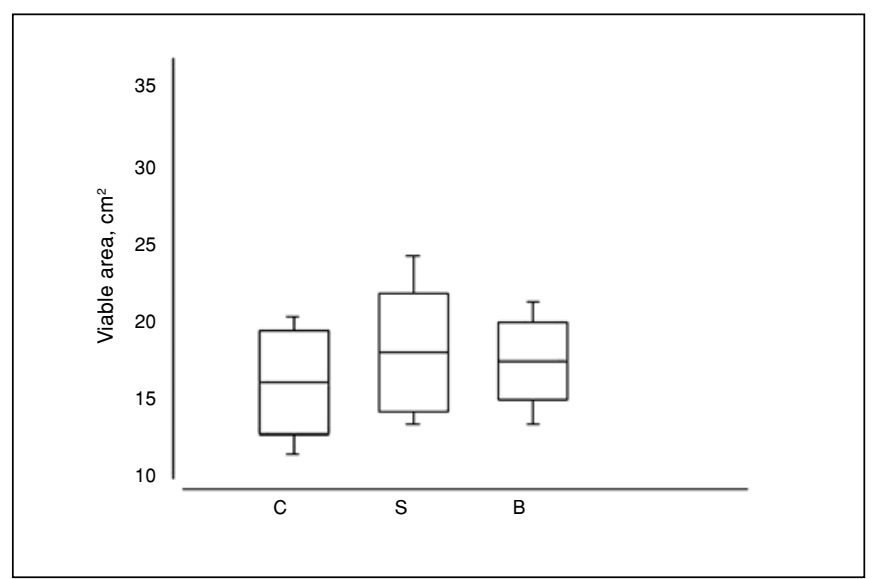

Figure 3 - Analysis of the viable areas, with no significant statistical difference observed among the three groups $(H=1.6475$, degrees of freedom $=2 ; P=0.4388)$. $B=$ buflomedil; $C=$ control; $S=$ sildenafil.

\section{DISCUSSION}

The data demonstrated that buflomedil's reported beneficial effect on microcirculation was not correlated with a reduction in ischemia in tissue flaps. However, some studies 


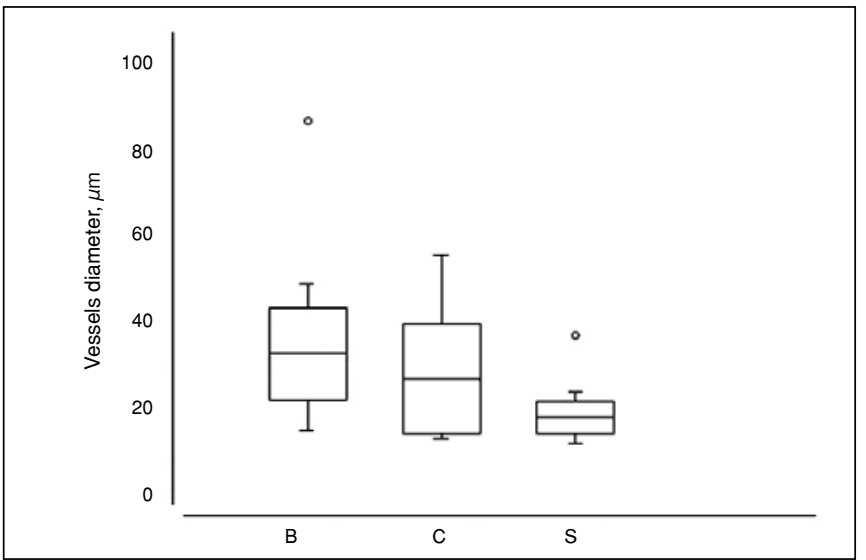

Figure 4-Microvessel diameter calculations from representative histological sections of the viable areas of flaps from animals in the buflomedil, control, and sildenafil groups. The Kruskal-Wallis $(P=0.02)$ test indicated statistically different results between the buflomedil and sildenafil groups $(P<0.05)$. The results of the buflomedil and sildenafil groups did not differ significantly from the results observed in the control group. $B=$ buflomedil;

$$
C=\text { control; } S=\text { sildenafil. }
$$

have shown conflicting results $3,6,7,11$. The studies that reported reduced tissue ischemia tested buflomedil at a dose of $3 \mathrm{mg} /$ $\mathrm{kg}$, intraperitoneally $\mathrm{y}^{6,7}$ or intravenously ${ }^{3,8}$. As the oral route was used in this study, a higher dose $(10 \mathrm{mg} / \mathrm{kg})$ of drug was administered to account for potentially poor absorption from the gastrointestinal tract. In humans, it is known that only approximately $30 \%$ of the drug is absorbed through the gastrointestinal tract. Therefore, although doses of 50-200 mg/ day are recommended when dosed intravenously, those doses are increased to 300-600 mg/day when administered orally ${ }^{12}$.

The ineffectiveness of buflomedil in this study was not unprecedented. A study conducted by Quirinia et al. ${ }^{4}$ indicated the failure of this drug to increase flap viability in rats at doses of $10 \mathrm{mg} / \mathrm{kg}$ using the intraperitoneal route. The efficacy of this drug for other applications (e.g., the treatment of intermittent claudication) is currently being questioned due to conflicting published results ${ }^{13}$.

Sildenafil, however, is a drug with vasodilating effects that could potentially benefit randomized flaps. Although sildenafil still has been infrequently evaluated for this indication, two relatively recent studies have suggested some degree of randomized flap viability improvement in rats ${ }^{5,9}$. However, in the study of Hart et al. ${ }^{5}$, the action of the drug throughout the postoperative period was followed and the observed improvement in tissue viability on the third postoperative day did not remain statistically different, relative to the control group, through the fifth and seventh days. Although the administration route and dosages were similar to these studies, a significant improvement in the area of flap necrosis was not evidenced, compared to the control and buflomedil groups.

\section{CONCLUSION}

The use of buflomedil or sildenafil failed to show a reduction in the necrotic area of randomized flaps in rats.

\section{REFERENCES}

1. Kerrigan CL. Skin flap failure: pathophysiology. Plast Reconstr Surg. 1983;72(6):766-77.

2. Myers MB, Cherry G. Causes of necrosis in pedicle flaps. Plast Reconstr Surg. 1968;42(1):43-50.

3. Galla TJ, Saetzler RK, Hammersen F, Messmer K. Increase in skinflap survival by the vasoactive drug buflomedil. Plast Reconstr Surg. 1991;87(1):130-6.

4. Quirinia A, Gottrup F, Viidik A. Failure of buflomedil to improve wound healing in ischaemic skin flaps. Scand J Plast Surg Hand Surg. 1996;30(2):81-7.

5. Hart K, Baur D, Hodam J, Lesoon-Wood L, Parham M, Keith K, et al. Short- and long-term effects of sildenafil on skin flap survival in rats Laryngoscope. 2006;116(4):522-8.

6. Dias LC, Foustanos A, Carreirão S, Souza Filho S, Pitanguy I. Influência do buflomedil na viabilidade de retalhos cutâneos. (Buflomedil influence in skin flaps viability) Rev Bras Cir. 1990;80(1):49-55.

7. Mauad RJ Jr, Shimizu MH, Mauad T, Tolosa EM. Buflomedil and pentoxifylline in the viability of dorsal cutaneous flaps of rats treated with nicotine. J Plast Reconstr Aesthet Surg. 2006;59(4):387-92.

8. Saetzler RK, Lerh HA, Barker JH, Kamler M, Galla TJ, Messmer K. Visualization of nutritive perfusion following tourniquet ischemia in arterial pattern skin flaps: effect of vasoactive medication. Plast Reconstr Surg. 1994;94(5):652-60.

9. Sarifakioglu N, Gokrem S, Ates L, Akbuga UB, Aslan G. The influence of sildenafil on random skin flap survival in rats: an experimental study. Br J Plast Surg. 2004;57(8):769-72.

10. Um SC, Suzuki S, Toyokuni S, Kim BM, Tanaka T, Hiai H, et al. Involvement of nitric oxide in survival of random pattern skin flap. Plast Reconstr Surg. 1998;101(3):785-92.

11. Uhl E, Rösken F, Curri SB, Menger MD, Messmer K. Reduction of skin flap necrosis by transdermal application of buflomedil bound to liposomes. Plast Reconstr Surg. 1998;102(5):1598-604.

12. Fredj GM, Clenet M, Rousselet F. Dosage du buflomédil dans les milieux biologiques: détermination des différents paramètres pharmacocinétiques. Therapie. 1978;33(3):321-32.

13. De BackerTL, Bogaert M, Vander Stichele R. Buflomedil for intermittent claudication. Cochrane Database Syst Rev. 2007;(4):CD000988. 